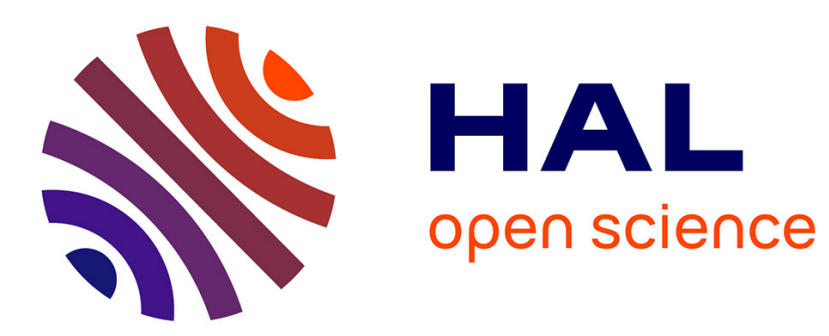

\title{
Depth distribution of benthic dinoflagellates in the Caribbean Sea
}

Aurélie Boisnoir, Pierre Yves Pascal, Sébastien Cordonnier, Rodolophe Lemée

\section{To cite this version:}

Aurélie Boisnoir, Pierre Yves Pascal, Sébastien Cordonnier, Rodolophe Lemée. Depth distribution of benthic dinoflagellates in the Caribbean Sea. Journal of Sea Research (JSR), 2018, 135, pp.74-83. 10.1016/j.seares.2018.02.001 . hal-01968144

\section{HAL Id: hal-01968144 https://hal.univ-antilles.fr/hal-01968144}

Submitted on 2 Jan 2019

HAL is a multi-disciplinary open access archive for the deposit and dissemination of scientific research documents, whether they are published or not. The documents may come from teaching and research institutions in France or abroad, or from public or private research centers.
L'archive ouverte pluridisciplinaire HAL, est destinée au dépôt et à la diffusion de documents scientifiques de niveau recherche, publiés ou non, émanant des établissements d'enseignement et de recherche français ou étrangers, des laboratoires publics ou privés. 


\author{
Aurélie Boisnoir ${ }^{\mathrm{a}, \mathrm{b}_{*}}$
}

4

\author{
Pierre-Yves Pascal ${ }^{\mathrm{a}}$
}

5 Sébastien Cordonnier ${ }^{\mathrm{a}}$

6 Rodolophe Lemée ${ }^{b}$

$7 \quad{ }^{a}$ UMR 7138 Evolution Paris-Seine, Equipe biologie de la mangrove, Université des Antilles, BP 592, 97159

8 Pointe-à-Pitre, Guadeloupe, France

9 b Sorbonne Universités, UPMC Univ Paris 6, INSU-CNRS, Laboratoire d'Océanographie de Villefranche,

10 Villefranche-sur-Mer, France

$11 *$ Corresponding author: aurelie.boisnoir@gmail.com

12 Key Words: Halophila stipulacea, Gambierdiscus, Ostreopsis, Prorocentrum

13 Running Head: Depth distribution of benthic dinoflagellates

14 
Monitoring of benthic dinoflagellates is usually conducted between sub-surface and

$175 \mathrm{~m}$ depth, where these organisms are supposed to be in highest abundances. However, 18 only few studies have focused on the small-scale depth distribution of benthic 19 dinoflagellates. In the present study, abundances of dinoflagellates were evaluated on an 20 invasive macrophyte Halophila stipulacea in two coastal sites in Guadeloupe along a depth 21 gradient from sub-surface to $3 \mathrm{~m}$ at Gosier and until $20 \mathrm{~m}$ at Rivière Sens during the tropical wet and dry seasons. Depth did not influence total dinoflagellate abundance but several genera showed particular depth-distribution preferences. The highest abundances of Ostreopsis and Gambierdiscus species were estimated preferentially in surface waters whereas Coolia spp. was found comparatively at depth. H. stipulacea biomass was positively correlated with Ostreopsis spp. abundance. Our study suggests that sampling of benthic dinoflagellates should be conducted at different water depths taking into account the presence of the macroalgal substrate as well. In the Caribbean area, special attention should be addressed to the presence of $H$. stipulacea which tends to homogenize the marine landscape and constitutes a substrate favourable for dinoflagellates growth.

\section{$\underline{\text { Introduction }}$}

Toxic harmful algal bloom occurrence is becoming more frequent and can cause more problems on ecosystems and human health at global scale (Hallegraeff, 1993; Cloern et al., 2005; Glibert et al., 2005; Hallegraeff, 2010). Several species of planktonic and benthic dinoflagellates can produce ecological damages to the environment and human

37 health when they bloom in excess. Decreased levels of oxygen in the water column when the blooms decay and/or production of toxins, can lead to mass mortalities of marine 
organisms (Shears and Ross, 2009) and/or to intoxication when toxins are transferred and

40 bioaccumulated in the food web (Yasumoto et al., 1987; Holmes and Teo, 2002). Those

41 toxins are accumulated within the food chain (Yasumoto et al., 1977; Adachi and Fukuyo, 1979; Lewis and Holmes, 1993; Gleibs and Mebs, 1999; Aligizaki et al., 2011). Phycotoxins potentially generate human intoxications through consumption of marine fishery products contaminated with bio-accumulated toxins (Valdiglesias et al., 2013). There are several poisoning syndromes caused by benthic dinoflagellates including, gastrointestinal (nausea, vomiting, diarrhoea) and/or neurological (tingling, headaches, dizziness, hallucinations, seizures) consequences (Ajani et al., 2017). These poisoning syndromes are mainly due to the presence of Ostreopsis spp., Prorocentrum spp. and Gambierdiscus spp. Ostreopsis spp. synthetize potent palytoxin and derivatives (Onuma et al., 1999; Lenoir et al., 2004) probably responsible for clupeotoxin fish poisoning (Onuma et al., 1999; Randall, 2005; Aligizaki et al., 2011) and palytoxicosis (Alcala et al., 1988) in tropical areas. In temperate regions, blooms of Ostreopsis spp. are the causal agent of skin and eye irritations (Ciminiello et al., 2006; Tichadou et al., 2010) and respiratory syndromes due to exposure of aerosolized toxins or cells (Ciminiello et al., 2014). Prorocentrum spp. produce okadaic acid and dinophysistoxins (Kumagai et al., 1986; Yasumoto et al., 1987; Faust and Gulledge, 2002; Nascimento et al., 2016; Luo et al., 2017) causing diarrheic shellfish poisoning for seafood consumers (Landsberg et al., 2005). Ciguatoxins produced by Gambierdiscus spp. are responsible of ciguatera fish poisoning (Chinain et al., 2010; Berdalet et al., 2017). This poisoning is the most common

60 non-bacterial food-borne illness (Tester, 1994; Tester et al., 2009) associated with consumption of several fish species (Bagnis, 1981; Tester et al., 2009; Dickey and Plakas, 2010). Ciguatera can lead to death in the most severe cases (Friedman et al., 2008). Coolia spp. and Amphidinium spp., synthetize toxins that can affect marine life but the 
64 bioaccumulation of these toxins through marine food chain and human poisoning have not

65 been proven (Holmes et al., 1995; Botana, 2014; Ben-Gharbia et al., 2016). To our knowledge, effects of Sinophysis spp. on human health have not been documented yet.

Blooms of benthic toxic dinoflagellates generates also economic problems for fishermen and aquaculture (Bagnis, 1981; Shumway, 1990; Bauder et al., 2001; HerediaTapia et al., 2002; Berdalet et al., 2015) whose consequences are difficult to quantify (Ahmed, 1991). For instance in Australia and French Polynesia the strategy to protect human health consisted, among other actions, on a decree banning the fishing and selling of several fish species (Bagnis, 1981; Lehane and Lewis, 2000) as their contamination cannot be easily measured (Ahmed, 1991). In Guadeloupe Archipelago selling of several fish species, known to cause sanitary problems, is prohibited. It is presently suspected that new fish species could be potential poisoning vectors representing a supplementary shortfall for Caribbean fisherman. For environmental, sanitary and economic reasons it is important to set up long time-scale monitoring of benthic dinoflagellates considering physicochemical parameters to know precisely the ecological niches of each species and to allow an efficient risk management due to toxic dinoflagellates.

Ostreopsis, Prorocentrum, Gambierdiscus, Coolia, Amphidinium, Sinophysis species are present in the Caribbean Sea (Ballantine et al., 1988; Morton and Faust, 1997; Faust, 2009; Chomérat, 2016). Usually, samplings are restricted to shallow depths, from the surface to $5 \mathrm{~m}$ depth (Chang et al., 2000; Okolodkov et al., 2007; Parsons and Preskitt, 2007; Mangialajo et al., 2008; Shears and Ross, 2009; Rahman Sha et al., 2014) where benthic dinoflagellates are supposed to be in highest abundances because they are considered to be mainly photosynthetic (Taylor, 1985; Faust, 1997; Ten-Hage et al., 2000; Fraga et al., 2008; Fraga and Rodríguez, 2014). However, these organisms are not necessarily restricted to the sub-surface as they can complement their autotrophic 
behaviour with the uptake of organic matter (Burkholder et al., 2008; Pistocchi et al., 2011; Jauzein et al., 2017).

Only few studies focused on depth distribution of benthic toxic dinoflagellates. A first approach is to consider several sites with different depths (Taylor, 1985; Richlen and Lobel, 2011) but observed differences can be due to local environmental conditions rather than depth effects. A way to limit this potential bias is to collect samples at different depths in a single area. The comparison at two different depths of the abundance of Gambierdiscus revealed a decrease in the first $10 \mathrm{~m}$ (Xu et al., 2014) and stability between depths of 10 and $20 \mathrm{~m}$ (Loeffler et al., 2015). A better way to evaluate the depth effect is to set up transects of sampling along a depth gradient. The study by Totti et al. (2010) was the only one considering a single substrate with this approach. As macrophytes are not often homogeneously distributed along this gradient, several macrophytes species are usually collected (Delgado et al., 2006; Cohu and Lemée, 2012; Cohu et al., 2013). When dinoflagellate abundances are coming from different macrophytes, dinoflagellates abundance comparisons are difficult because normalizing cell counts to the weight of the macroalgal host introduces a significant source of error due to different surface area to mass ratios of each host algal species (Richlen and Lobel, 2011). Previous studies have suggested a host preference of dinoflagellates depending on the macrophyte morphology (Parsons and Preskitt, 2007; Totti et al., 2010), taxonomic group (Morton and Faust, 1997; Delgado et al., 2005; Monti et al., 2007; Parsons et al., 2017) or species (Ballantine et al., 1985; Delgado et al., 2005). Furthermore, such macroalgae could produce molecules stimulating or inhibiting growth of benthic dinoflagellates (Grzebyk et al., 1994; Morton and Faust, 1997; Accoroni et al., 2015). Such allelopathic interactions between macroalgae and benthic dinoflagellates can induce bias in abundances comparisons. Several methods were recently set up to minimize bias due to host preferences and avoid macrophyte 
114 destruction. Artificial substrates need $24 \mathrm{~h}$ of incubation to have a comparable colonization

115 between them and macrophytes at the same sampling locations (Tester et al., 2014; Jauzein

116 et al., 2016). However, this method is collecting resuspended dinoflagellates without direct

117 contact with the benthic stock of microalgal population (Jauzein et al., 2016) but a positive

118 correlation was found between planktonic and benthic abundances in several studies

119 (Aligizaki and Nikolaidis, 2006; Mangialajo et al., 2011). Benthic dinoflagellates

120 integrator called "BEDI" (Mangialajo et al., 2017) and syringe (Abbate et al., 2012)

121 methods are faster than artificial substrates but they would be difficult to adapt to low

122 abundances of dinoflagellates in tropical regions.

123 The aim of the present study is to describe the natural depth distribution of harmful

124 benthic dinoflagellates at genus level, in the Caribbean Sea. To avoid variations due to

125 spatial ecosystem heterogeneity and variations linked to biotic substrates, a single

126 macrophyte species, Halophila stipulacea Fosskal, was regularly sampled along a depth

127 gradient in two sites in Guadeloupe. H. stipulacea is an invasive seagrass noticed for the

128 first time in 2002 in Grenada (Ruiz and Ballantine, 2004), now established in the Eastern

129 Caribbean (Willette et al., 2014) and presenting large mono-specific meadows (Willette

130 and Ambrose, 2012). This seagrass is native from the Red Sea and Persian Gulf (den

131 Hartog, 1970). Rapid lateral bed expansion combined with its tolerance for a wide

132 spectrum of environmental conditions allows $H$. stipulacea to exclude dominant seagrasses

133 in the Caribbean (Willette and Ambrose, 2012). To our knowledge enumerations of

134 benthic dinoflagellates have never been done on Halophila stipulacea. 
137 Sampling of H. stipulacea was conducted in the morning by scuba diving during the 138 wet season on September $21^{\text {st }}$ and $22^{\text {nd }} 2015$ and during the dry season on February $1^{\text {st }}$ and

$1392^{\text {nd }}$ respectively at Gosier $\left(16^{\circ} 13^{\prime} 25.1^{\prime \prime} \mathrm{N}, 61^{\circ} 31^{\prime} 50^{\prime \prime} \mathrm{W}\right)$ and Rivière Sens $\left(15^{\circ} 58^{\prime} 51.8^{\prime} \mathrm{N}\right.$, $14061^{\circ} 42^{\prime} 59.2^{\prime \prime} \mathrm{W}$ ) in Guadeloupe (French West Indies) (Fig. 1). Sampling was conducted 141 according to the distribution and availability of $H$. stipulacea in each site. In the shallow 142 site (Gosier), samples were collected every $0.5 \mathrm{~m}$ from $0 \mathrm{~m}$ depth to $3 \mathrm{~m}$ depth as $H$. 143 stipulacea was absent deeper. In the deep site (Rivière Sens), samples were collected every $1440.5 \mathrm{~m}$ from $4 \mathrm{~m}$ to $10 \mathrm{~m}$ depth then every $5 \mathrm{~m}$ until $20 \mathrm{~m}$ depth as $H$. stipulacea was absent 145 from the surface to $4 \mathrm{~m}$ depth. Samples were taken in triplicate $(\mathrm{n}=3)$ at each sampled 146 depth. In Guadeloupe, tides are semidiurnal with a mean tidal amplitude of $30 \mathrm{~cm}$ (tide 147 gauge of Pointe-à-Pitre, REFMAR®).

149 For each depth, triplicate samples of Halophila stipulacea with their surrounding 150 water were taken carefully in $250 \mathrm{~mL}$ plastic flasks avoiding microalgae resuspension from 151 the macroalgae. Acidic Lugol at $1 \%$ (vol/vol) was added in all samples to fix microalgae 152 and 10 seconds agitation allowed to dislodge benthic dinoflagellates present on 153 macrophyte. Samples were passed through a $500 \mu \mathrm{m}$ mesh to separate the macrophyte 154 from water containing dinoflagellates. To recover a maximum of dinoflagellates, $H$. stipulacea was rinsed twice for 10 seconds with $100 \mathrm{~mL}$ of filtered seawater and then

156 weighted. Total seawater volume was measured. Samples were stocked in the dark at $4{ }^{\circ} \mathrm{C}$.

157 Benthic dinoflagellates present in $1 \mathrm{~mL}$ were counted with a Sedgewick Rafter @ counting 158 cell using a standard light microscope less than one week after the sampling. This 159 abundance and macrophyte's fresh weight allowed calculation of the number of benthic 
160 toxic dinoflagellates per gram of fresh weight of $H$. stipulacea (cells.gFW ${ }^{-1}$ ). An average

161 cellular abundance was estimated per depth, for all species of benthic toxic dinoflagellates $162(n=3)$.

All H. stipulacea present in $20 \times 20 \mathrm{~cm}$ square surface were sampled in triplicate at each depth and kept in the dark at $-4^{\circ} \mathrm{C}$. H. stipulacea content of each square was weighed

167 after defrosting, rinsing and drying with absorbent paper and an average biomass of macrophyte per square meter was calculated for each depth. Measurement of $H$. stipulacea

169 weight was used to estimate the density of benthic dinoflagellates per square meter of sea 170 bottom (cells.m $\left.{ }^{-2}\right)$.

$$
\text { cells. } \mathrm{m}^{-2}=\frac{10000 \text { (H. stipulacea biomass) }}{400} \times \text { cells. } g F W^{-1}
$$

172 Thirty entire limbs of $H$. stipulacea of each triplicate were measured (length and width)

173 with a calliper. Measurement of leaf length and width was used to estimate leaf surface 174 considering rectangular geometric shape of each leaf.

A sample of $250 \mathrm{ml}$ of seawater surrounding $H$. stipulacea was used to measure

177 environmental factors at every depths. Temperature was measured immediately with a

178 Checktemps 4 HANNA thermometer and salinity was determined in the laboratory with a Master-S/MilliM ATAGO ${ }^{\circledR}$ manual refractometer. A SCUBAPRO Aladin Tec 3G dive

180 computer was used to measure depth of sea bottom. 
182 Non-parametric tests were used as variances of $H$. stipulacea biomasses and benthic 183 dinoflagellates abundances were not normally distributed. Kruskal-Wallis tests were

184 utilised to assess $H$. stipulacea biomass and benthic dinoflagellates abundances related to 185 depth. Dunn test is a multiple comparison method permitting to compare the mean of the 186 rank of each treatment after a Kruskal-Wallis test. The normal distribution is used as the 187 asymptotic distribution of the standardized difference of the mean of the ranks. Mann

188 Whitney test was performed to assess ( $i$ ) differences in temperature and salinity between 189 the wet and the dry seasons, (ii) variations of $H$. stipulacea biomass between both seasons 190 and (iii) to determine influence of seasons on abundances of dinoflagellates. Spearman 191 correlation tests were applied to determine potential relationships between environmental 192 parameters and dinoflagellate abundances. All descriptive analyses are presented as mean $193 \pm$ standard deviation (SD).

194 $\underline{\text { Results }}$ Ecological parameters at Gosier and Rivière Sens

At Gosier, average temperature of water column during the wet and dry seasons 198 varied from $30.9 \pm 0.5^{\circ} \mathrm{C}$ to $27.3 \pm 0.3^{\circ} \mathrm{C}$ and salinity fluctuated from $30 \pm 1$ to $35 \pm 0$ 199 (Figure 2). At Rivière Sens, seawater temperature varied from $29.4 \pm 0.1^{\circ} \mathrm{C}$ to $26.5 \pm 0.4^{\circ} \mathrm{C}$ 200 and salinity from $31 \pm 1$ to $36 \pm 0$ during the two sampled seasons. At both sites, 201 temperatures were warmer during the wet than the dry season $(p<0.01)$ and salinity was on 202 average higher during the dry than the wet season $(\mathrm{p}<0.003)$. 
At Gosier, average biomass of $H$. stipulacea did not change with depth during the wet and dry seasons $(\mathrm{p}<0.051)$. H. stipulacea biomass averaged $803 \pm 392 \mathrm{~g} \cdot \mathrm{m}^{-2}$ and was statistically not different during the two seasons $(\mathrm{p}=0.564)$ (Figure 3). At Rivière Sens, average biomass of $H$. stipulacea did not change with depth during the dry season but it was higher at depth during the wet season $(\mathrm{p}=0.008)$ (Fig 3). Biomass of H. stipulacea was higher at the dry $\left(1075 \pm 445\right.$ g.m $\left.\mathrm{m}^{-2}\right)$ than the wet season $\left(528 \pm 329\right.$ g.m $\left.\mathrm{m}^{-2}\right)(\mathrm{p}<0.0001)$.

Leaf surface of $H$. stipulacea significantly increased with depth at both sites $(\mathrm{p}=0.0001)$. At Gosier, leaf surfaces were statistically higher at $2.5 \mathrm{~m}$ depth $\left(3.4 \pm 1.1 \mathrm{~cm}^{2}\right)$ than these collected at $0 \mathrm{~m}$ and $0.5 \mathrm{~m}$ depth $\left(2.1 \pm 0.7 \mathrm{~cm}^{2}\right)$. At Rivière Sens, the highest leaf areas were at $15 \mathrm{~m}$ and $20 \mathrm{~m}$ depths $\left(2.9 \pm 1.3 \mathrm{~cm}^{2}\right)$ and smallest between $4 \mathrm{~m}$ and 7 $\mathrm{m}$, and at $10 \mathrm{~m}$ depths $\left(1.5 \pm 0.5 \mathrm{~cm}^{2}\right)$ (Figure 3).

\section{Abundances of benthic dinoflagellates and depth distribution}

Ostreopsis spp., Prorocentrum spp., Coolia spp., Amphidinium spp. and Sinophysis

were found during this survey. Ostreopsis spp. and Prorocentrum spp. were found in higher abundances than the other genera.

At Gosier, abundances of benthic dinoflagellates decreased with depth during the wet season $(\mathrm{p}=0.008)$. The highest average abundances of benthic dinoflagellates were observed at $0 \mathrm{~m}$ depth $\left(2079 \pm 831\right.$ cells.gFW $\left.{ }^{-1}\right)$ while no cells were found at $3 \mathrm{~m}$ depth (Figure 4). Ostreopsis was the dominant genus reaching $1669 \pm 1027$ cells.gFW ${ }^{-1}$ at $0 \mathrm{~m}$ depth and $120 \pm 17$ cells.gFW ${ }^{-1}$ at $1 \mathrm{~m}$ depth. For similar depths, abundances of

224 Prorocentrum were respectively $262 \pm 110$ and $77 \pm 52$ cells.gFW ${ }^{-1}$. Abundances of 225 Gambierdiscus spp. decreased from $113 \pm 104$ cells.gFW ${ }^{-1}$ at $0 \mathrm{~m}$ depth to $79 \pm 43$ 226 cells.gFW ${ }^{-1}$ at $2.5 \mathrm{~m}$ depth. Maximum abundances were observed at $0 \mathrm{~m}$ depth for Amphidinium spp. $\left(18 \pm 16\right.$ cells.gFW $\left.{ }^{-1}\right)$, at $1 \mathrm{~m}$ depth for Coolia $\mathrm{spp} .(22 \pm 21$ cells.gFW 
$\left.228^{1}\right)$ and at $1.5 \mathrm{~m}$ depth for Sinophysis spp. $\left(9 \pm 16\right.$ cells.gFW $\left.^{-1}\right)$. Abundances of benthic

229 dinoflagellates changed also with depth during the dry season $(\mathrm{p}=0.026)$. The highest

230 abundances were found at $1.5 \mathrm{~m}$ depth while no cell was found at $2.5 \mathrm{~m}$. Prorocentrum

231 spp. dominated other genera of benthic dinoflagellates (Figure 4). The highest average

232 abundances of Ostreopsis spp and Prorocentrum spp. were respectively at $0.5 \mathrm{~m}$ depth (75

$233 \pm 62$ cells.gFW $\left.{ }^{-1}\right)$ and $1.5 \mathrm{~m}$ depth $\left(939 \pm 718\right.$ cells.gFW $\left.\mathrm{gF}^{-1}\right)$. Abundances of

234 Gambierdiscus, Coolia, Amphidinium and Sinophysis genera were constant during both seasons. They never exceeded an average abundance of 30 cells.gFW ${ }^{-1}$. Abundances of benthic dinoflagellates did not differ between the wet and the dry seasons $(\mathrm{p}=0.150)$.

At Rivière Sens, abundances of benthic dinoflagellates changed with depth during wet season $(\mathrm{p}=0.036)$. The highest abundances were observed at 7 and $8 \mathrm{~m}$ depths $(753 \pm$

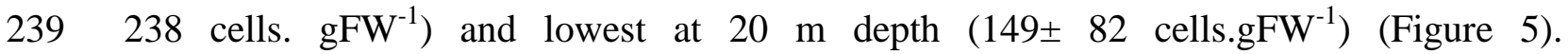

240 Prorocentrum spp. dominated the benthic dinoflagellate assemblage. The highest mean

241 abundances were observed during the sampled period at depth of $4 \mathrm{~m}$ for Ostreopsis spp.

$242\left(30 \pm 51\right.$ cells. $\left.\mathrm{gFW}^{-1}\right), 5 \mathrm{~m}$ for Sinophysis spp. $\left(28 \pm 30\right.$ cells.gFW $\left.{ }^{-1}\right), 7 \mathrm{~m}$ for Sinophysis 243 spp. $\left(28 \pm 30\right.$ cells. $\left.\mathrm{gFW}^{-1}\right), 8 \mathrm{~m}$ for Prorocentrum spp. $\left(676 \pm 254\right.$ cells.gFW $\left.{ }^{-1}\right), 8-9 \mathrm{~m}$ 244 for Coolia spp. $\left(60 \pm 42\right.$ cells.gFW $\left.{ }^{-1}\right)$ and $15 \mathrm{~m}$ for Amphidinium spp. $\left(31 \pm 31\right.$ cells. $\mathrm{gFW}^{-}$ $245^{1}$ ). Abundances of benthic dinoflagellates varied with depth also during the dry season $(\mathrm{p}=0.003)$. The highest abundance was at $4 \mathrm{~m}\left(1850 \pm 656\right.$ cells.gFW $\left.{ }^{-1}\right)$ and lowest was at

$24720 \mathrm{~m}$ depth $\left(26 \pm 45\right.$ cells.gFW $\left.{ }^{-1}\right)$ (Fig 5). Ostreopsis spp dominated the community of 248 benthic dinoflagellates overall. From 4 to $6 \mathrm{~m}$ Ostreopsis spp. dominated Prorocentrum 249 spp. with respective abundances of $930 \pm 433$ cells $\mathrm{gFW}^{-1}$ and $619 \pm 282$ cells.gFW ${ }^{-1}$ 250 whereas from 7 to $9 \mathrm{~m}$ Prorocentrum spp. dominated Ostreopsis spp. with respective 251 abundances of $307 \pm 143$ cells $\mathrm{gFW}^{-1}$ and $181 \pm 91$ cells.gFW ${ }^{-1}$. The highest abundances 252 were observed at depth of $6 \mathrm{~m}$ for Coolia spp. (59 \pm 67$), 7 \mathrm{~m}$ for Sinophysis spp. $(21 \pm 36)$, 
$2538 \mathrm{~m}$ for Gambierdiscus spp. (16 \pm 14$)$ and $9 \mathrm{~m}$ for Amphidinium spp. (20 \pm 22$)$. The 254 abundances for these genera were low.

255 Abundances of benthic dinoflagellates were similar during the wet and the dry season $256 \quad(\mathrm{p}=0.387)$.

257 Preferential depth of Ostreopsis spp. and Prorocentrum spp. changed according to 258 the dominant genus. Prorocentrum spp. present a peak of abundance deeper than 259 Ostreopsis spp. when Prorocentrum spp. dominated the benthic dinoflagellates community 260 (Gosier during the dry season and Rivière Sens during the wet season). Furthermore, peak 261 abundances of Prorocentrum spp. and Ostreopsis spp. occurred at the same depth when 262 Ostreopsis spp. were dominant in the microalgae community (Gosier during the wet season 263 and Rivière Sens during the dry season). Concerning Coolia spp., Amphidinium spp. and 264 Sinophysis spp., the depth of the peak abundances changed between the seasons at Riviere 265 Sens. Peak abundances of Coolia spp. and Amphidinium spp. were deeper during the wet season than the dry season at Rivière Sens. The highest abundances of Coolia spp. and Amphidium spp. were found respectively at 8-9 m depths and $15 \mathrm{~m}$ respectively during the wet season while highest abundances of these genera where at $6 \mathrm{~m}$ depth and $8 \mathrm{~m}$ depth respectively. However, the depth of peak abundance of Sinophysis spp. was shallowest during the wet season (5 $\mathrm{m}$ depth) than the dry season (8 $\mathrm{m}$ depth). Coolia spp., Amphidinium spp. and Sinophysis spp. have not been found during the dry season at

272 Gosier.

Temperature, salinity and benthic dinoflagellates

Highest Ostreopsis spp. abundances occurred for the wet season at Gosier with an optimal salinity of $31.3^{\circ} \mathrm{C}$ and $31.4^{\circ} \mathrm{C}$ while the highest abundance of Ostreopsis spp. was

277 observed at $26.8^{\circ} \mathrm{C}$ for the wet season at Rivière Sens. Ostreopsis spp. abundances 
occurred in maximal abundance during the dry season when evaporation was maximal and

279 with a water salinity of 36 . Highest abundances of Prorocentrum spp. were observed

280 during the dry season with a temperature of $27.4^{\circ} \mathrm{C}$ and a salinity of 35 . The highest

281 abundance of Gambierdiscus spp. were found at the shallow site (Gosier) during the wet 282 season when seawater temperature was the warmest above $30^{\circ} \mathrm{C}$ and when salinity was of 28330.

284 The highest abundances of Coolia spp. were found during the warmest season (the wet 285 season), when temperature was included between $29.4^{\circ} \mathrm{C}$ and $31^{\circ} \mathrm{C}$ with a salinity of seawater of 30. Highest abundances of Amphidinium spp. were found at Gosier and at

287 Rivière Sens during the wet season when temperature and salinity were above $29^{\circ} \mathrm{C}$ and 30

288 respectively. Highest abundances of Sinophysis spp; were found at Riviere Sens, the 289 deepest site when temperature was comprised between $26.8^{\circ} \mathrm{C}$ and $29.8^{\circ} \mathrm{C}$ and salinity 290 included 30-36.

Relation between environmental parameters measured at both sites (Rivière Sens and

293 Gosier) and benthic dinoflagellates abundances (cells. $\mathrm{gFW}^{-1}$ ) has been analysed together with a Spearman correlation. None of the studied environmental parameters were significantly linked with total average abundances of benthic toxic dinoflagellates but they

296 influenced several genera independently. The depth, salinity and biomass of $H$. stipulacea

297 (g.m $\mathrm{m}^{-2}$ ) were weakly correlated with abundance of benthic dinoflagellates (cells. $\mathrm{gFW}^{-1}$ ).

298 The depth was negatively correlated with Ostreopsis spp. and Gambierdiscus abundances 299 while the depth was positively correlated with Amphidinium spp.. The salinity was 300 positively correlated with Ostreopsis spp. and negatively correlated with Gambierdiscus 301 spp. abundances. The temperature was positively correlated with Gambierdiscus spp. only 
302 (Table 1). Also, a weak positive correlation between Ostreopsis spp. abundances and $H$.

303 stipulacea biomass was found.

304 Abudances of several genera of benthic dinflagellates were weakly correlated

305 between them. Ostreopsis spp. abundances were correlated with Prorocentrum spp.,

306 Gambierdiscus spp., and Amphidinium spp.. Prorocentrum spp. were correlated with

307 Coolia spp. Amphidinium spp. and Sinophysis spp. Only weak positive correlations were

308 found between Coolia spp. Amphidinium spp. and Gambierdiscus spp. and total 309 abundances of benthic dinoflagellates while total abundances were strongly correlated with 310 abundance of Ostreopsis spp. and Prorocentrum spp..

$311 \quad$ Density of benthic dinoflagellates

312 At Gosier the highest abundances of dinoflagellates per square meter were observed

313 at $0 \mathrm{~m}$ depth $\left(6.910^{5} \pm 2.910^{4}\right.$ cells.m ${ }^{-2)}$ during wet season and at $1.5 \mathrm{~m}$ depth $\left(7.010^{5} \pm\right.$

$3146.510^{5}$ cells. $\mathrm{m}^{-2}$ ) during the dry season ( $\mathrm{p}=0.037$ ) (Figure 6). No difference of total density

315 of benthic dinoflagellates was found between the wet and the dry season $(p=0.115)$.

316 At Rivière Sens the highest abundances of dinoflagellates per square meter were 317 observed at $7 \mathrm{~m}$ and $8 \mathrm{~m}$ depths $\left(3.910^{5} \pm 2.010^{5}\right.$ cells. $\left.^{-2}\right)$ during the wet season $318(\mathrm{p}=0.0024)$ and at $6 \mathrm{~m}\left(2.110^{6} \pm 9.110^{5}\right.$ cells. $\left.\mathrm{m}^{-2}\right)$ during the dry season $(\mathrm{p}=0,003)$. Total 319 densities of benthic dinoflagellates were similar between the wet and the dry season. $320 \quad(\mathrm{p}=0.053)$.

\section{$\underline{\text { Discussion }}$}

This study examined the depth effect on abundances of epiphytic dinoflagellates.

325 Samples were collected on similar natural substrate at different depths in Guadeloupe at 
326 Gosier and Rivière Sens. This approach was possible thanks to the presence of

327 monospecific meadows of $H$. stipulacea along a depth gradient at both sites. However, 328 none area presented a continuous populations of $H$. stipulacea from the surface to $25 \mathrm{~m}$ 329 depth. Distribution of dinoflagellates was consequently observed in shallow depth at 330 Gosier and deeper at Riviere Sens.

331 This is a novel study, because no dinoflagellate census has been realized in

332 Guadeloupe so far. Only genera were determined in this study due to morphological 333 identification difficulties leading to determination confusions. Morphogenetic analysis of 334 benthic dinoflagellates present in Guadeloupe and Martinique are under investigation. 335 Furthermore, to our knowledge enumerations of benthic dinoflagellates have never been 336 done on Halophila stipulacea,

337 Among the studied parameters, the depth was the principal factor affecting 338 Ostreopsis spp. distribution with higher abundances found at the lower depths sampled.

339 Similar trends on depth distribution were also observed in the Pacific Ocean (Richlen and 340 Lobel, 2011) and the Mediterranean Sea (Totti et al., 2010; Cohu et al., 2013) potentially 341 linked with light intensity (Totti et al., 2010). However, this study did not allow to identify 342 separately effects of light intensity and depth on Ostreopsis spp. distribution. Ostreopsis 343 spp. occurred in maximal abundances with higher salinity in present survey. Indeed, the 344 optimal salinity for growth of Ostreopsis spp. in the Caribbean area was 33 (Morton et al., 345 1992). Also, the temperature was not an ecological factor correlated to abundances of 346 Ostreopsis spp. in this study. However, maximal abundances of Ostreopsis spp. were 347 included between $26.8^{\circ} \mathrm{C}$ and $31.4^{\circ} \mathrm{C}$ in this survey while optimal growth for this genus were $25^{\circ} \mathrm{C}$ (Morton et al., 1992). The temperature was not found to be contributing to Ostreopsis spp. seasonal fluctuations in the Caribbean area (Ballantine et al., 1988;

350 Okolodkov et al., 2007) as in temperate waters (Vila et al., 2001). However, in other 
studies conducted in the Mediterranean Sea, the highest abundances of Ostreopsis spp. were found when surface seawater temperature was the highest (Aligizaki and Nikolaidis, 2006; Mangialajo et al., 2008).

354 The depth is the environmental factor with the lowest influence on Gambierdiscus spp. abundances. According to different studies, abundances of Gambierdiscus were not affected by depth, increased with depth (Richlen and Lobel, 2011) or decreased with depth (Taylor, 1985; Xu et al., 2014). In the present study, abundances were higher in shallow environments. The same trend existed in Pacific Ocean where Gambierdiscus spp. abundance at 2-3 m depth exceeded abundances at 10-15 $\mathrm{m}$ depth ( $\mathrm{Xu}$ et al., 2014).

360 Similar distributions were observed in different islands of the Caribbean Sea (Taylor, 361 1985) with a peak of abundance between $0.5 \mathrm{~m}$ and $3 \mathrm{~m}$ depth. It have been suggested that

362 absence of Gambierdiscus spp. in surface water could be explained by decreased salinity 363 due to rainy events (Taylor, 1985). This explanation can be excluded for this study as increased salinity during the dry season at Rivière Sens has not lead to increased abundances of Gambierdiscus spp.. Furthermore, highest abundances of Gambierdiscus spp. were found in this study during the wet season (season with the lowest seawater salinities) and at depths where the salinity was the lowest during this period suggesting seasonal salinities have more impact than salinity variations with depth. Also, the highest abundances of Gambierdiscus spp. were found at Gosier during the wet season and when the seawater temperature was the warmest of this study (above $\left.30^{\circ} \mathrm{C}\right)$. Optimal growth of

371 Gambierdiscus spp. from the Caribbean region was observed at conditions close to the

372 environment conditions with temperature of $29^{\circ} \mathrm{C}$ and salinity of 30 (Morton et al., 1992).

373 Abundances of Gambierdiscus spp. found in this study were particularly low contrary to monitoring conducted in the Caribbean area (Ballantine et al., 1988, 1985; Bomber et al., 1989). Seasonal fluctuations of Gambiersicus spp. are still unknown in Guadeloupe. 
376 A positive correlation existed between Coolia spp. abundances and depth in this study. In

377 the Mediterranean Sea this genus was observed at depths higher than $3 \mathrm{~m}$ (Cohu and 378 Lemée, 2012). Coolia spp. distribution is often neglected in studies conducted in the tropical areas. Furthermore, among ecological study carried out in tropical areas and

380 focusing on the depth none study has showed distribution of Coolia spp.. Only information 381 about low abundances of Coolia spp. $\left(<1000\right.$ cells.gFW $\left.{ }^{-1}\right)$ have been found in these 382 studies (Delgado et al., 2005; Xu et al., 2014). Coolia spp. present in the Caribbean area 383 exhibited optimal growth with a salinity of 33 and a temperature of $29^{\circ} \mathrm{C}$ (Morton et al., 384 1992). The results of this ecological study corroborated partially results of this study 385 because highest abundances of Coolia spp. were found during the warmest period (the wet 386 season), when temperature was included between $29.4^{\circ} \mathrm{C}$ and $31^{\circ} \mathrm{C}$ and with a salinity of 387 seawater of 30 . Coolia spp. were first reported to synthesize toxins in the early work 388 (Holmes et al., 1995) but none strains examined by Penna et al., (2005) were toxic and 389 Rhodes et al., (2000) have found both toxic and nontoxic strains. The toxicity variation of 390 Coolia spp. is difficult to interpreted and cannot be linked with a problem of identification 391 because taxonomic problems have not been reported for this genus (Penna et al., 2005).

392 Effects of Coolia spp. on human health are still unknown (Zingone et al., 2006). In fact, despite some initial studies suggested that the species produced cooliatoxin. (Holmes et al., 1995), further tests indicated that Coolia spp. is not toxic (Delia et al., 2015).

396 Higher abundances of Amphidinium spp. were found in this survey with different 397 temperature and salinity promoting optimal growth of Amphidinium spp. Indeed, the ecological study conducted on Caribbean benthic dinoflagellates has found an optimal growth temperature between $26^{\circ} \mathrm{C}$ and $28^{\circ} \mathrm{C}$ and a salinity of 34 . This genus was found in 
400 lowest abundances in Republic of Kiribati (0-12 cells.gFW $\left.{ }^{-1}\right)$ but distribution of

401 Amphidinium spp. has not been studied according to the depth (Xu et al., 2014)

402 Sinophysis spp. have been neglected by the ecological study.

403

404

Species interactions

405

The Prorocentrum spp. peak of abundances was always deeper than the Ostreopsis

406

spp. peak of abundance when Prorocentrum genus dominated the dinoflagellate

407

community. However peaks of abundance of Ostreopsis and Prorocentrum genera

408

occurred in surface and at the same depth when Ostreopsis spp. dominated the benthic

409 dinoflagellates assemblage. Richlen and Lobel (2011) suggested habitat separation

410 between both genera. Nevertheless, in this study abundances of Ostreopsis spp. and

411 Prorocentrum spp. were positively correlated, suggesting common preferences and

412 possible competition phenomena and/or allelopathic interactions. The temporal

413 fluctuations of benthic dinoflagellates are still unknown in Guadeloupe. However,

414 monitoring conducted in the Caribbean Sea and the Gulf of Mexico have observed a

415 characteristic dominance of Prorocentrum spp. in the benthic dinoflagellate assemblage

416 (Delgado et al., 2005; Okolodkov et al., 2014; Martinez-Cruz et al., 2015; Morton and

417 Faust, 1997). These previous studies support the dominance of Prorocentrum spp. at

418 Gosier and at Rivière Sens during the dry and the wet season respectively in this study.

419 Despite the dominance of Ostreopsis spp. seems to be unusual in the Caribbean Sea, this

420 prevalence was found in few Caribbean monitoring however none Prorocentrum spp.

421 abundance were mentioned (Ballantine et al., 1988). These results sustain dominance of

422 Ostreopsis spp. found in this study at Gosier and at Rivière Sens during the wet and the dry

423 season respectively. Furthermore, few studies have been conducted on allelopathic

424 interactions of benthic dinoflagellates (Richlen and Lobel, 2011). Prorocentrum, 
Ostreopsis, Gambierdiscus, Coolia, and Amphidinium are known to synthetize

426 allelochemical components inhibiting growth of microalgae (Sugg and VanDolah, 1999;

427 Legrand et al., 2003; Graneli et al., 2008). Assimilation of nutrients and environmental

428 factors affect toxins content of benthic dinoflagellates (Pezzolesi et al., 2012). P-nutrition

429 has been shown to influence toxin production. A rapid P-uptake within few days was found

430 for Ostreopsis spp. (Pezzolesi et al., 2014) and Prorocentrum spp. (Vanucci et al., 2010)

431 suggesting Ostreopsis spp. and Prorocentrm spp. could compete. Recently, Ostreopsis spp.

432 was found to favour cell attachment of Prorocentrum spp. with a positive dose dependent

433 relationship while cell lysis was observed at the same time for Gambierdiscus spp.

434 (García-Portela et al., 2016). All these strategies highlight complexity of allelopathic

435 interactions used by benthic dinoflagellates and could explain different distributions of 436 dinoflagellates along the depth

437 Gambierdiscus spp., Amphidinium spp., Coolia spp. and Sinophysis spp. were 438 abundances dependent. They co-occurred in low abundances. Positive correlations were 439 also found between Coolia spp., Ostreopsis spp. and Prorocentrum spp., as in the 440 Mediterranean Sea (Cohu and Lemée, 2012).

441 To our knowledge enumerations of benthic dinoflagellates have never been done on 442 Halophila stipulacea. In the Caribbean Sea, seagrass species are known to support lower 443 dinoflagellate abundances than macroalgae (Taylor, 1985; Morton and Faust, 1997). 444 However (Okolodkov et al., 2007) found the highest abundance of Prorocentrum spp. (31 445467 cells. $\mathrm{gFW}^{-1}$ ) on Thalassia testudinium, a seagrass, present in the Gulf of Mexico 446 (Okolodkov et al., 2007). This is about 18 times more than the maximum of Prorocentrum 447 spp. found in this study. At Belize (Morton and Faust, 1997) the lowest total abundance of 448 benthic dinoflagellates was found on $T$. testudinium and was comparable with average 449 abundances found in Guadeloupe found on H. stipulacea. 
Some previous studies have suggested a host preference of benthic Ostreopsis spp. depending on the macrophyte morphology with higher abundances on branched thalli

453 (Totti et al., 2010), on Phaeophyceae and Florideophyceae (Monti et al., 2007) and on

Dictyota sp. (Ballantine et al., 1985). However, more detailed studies on selected seagrass species are still lacking (Martinez-Cruz et al., 2015). In this study, a weak positive correlation was found between Ostreopsis spp. abundances (cells.gFW ${ }^{-1}$ ) and H. stipulacea biomass $\left(\mathrm{g} \cdot \mathrm{m}^{-2}\right)$. An ecological study with enumeration of benthic dinoflagellates present on different macrophytes and $H$. stipulacea must be conducted in Guadeloupe in order to confirm a preferential association between Ostreopsis spp. and H. stipulacea. At Rivière Sens, biomass and leaf surface of $H$. stipulacea increased with depth. A similar pattern was also observed for this species in the Mediterranean (Procaccini et al., 1999). However, availability of space for attachment on macrophyte does not seem to be the main limiting factor for dinoflagellates because during the wet season their maximum 464 abundance was located at 7-8 $\mathrm{m}$ depths while leaf surface is maximal at $15-20 \mathrm{~m}$ depth. A dense vegetation cover increases available surface colonisable by benthic dinoflagellates but it also decreases light irradiance necessary for the photosynthesis of dinoflagellates limiting their growth.

Halophila stipulacea is a seagrass grazed by fish (Mariani and Alcoverro, 1999) and turtles (Becking et al., 2014). Presence of dinoflagellates at each depth on H. stipulacea must be considered as a risk allowing the entrance of phycotoxins in the food web via herbivorous behaviour regardless of depth. This invasive seagrass would contribute to toxic dinoflagellates growth and persistence of ciguatera fish poisoning in the Caribbean 473 region which is the second area of the word affected by this disease (Chinain et al., 2014).

474 Monitoring of benthic toxic dinoflagellates present on $H$. stipulacea should be set also in 
475 Mediterranean Sea to assess capacity of this macrophyte to support toxic benthic 476 dinoflagellates. Until 2007, H. stipulacea was too sparse to coexist under canopy of the 477 large native seagrasses of Mediterranean Sea (Williams, 2007). Actually mono-specific 478 meadows of $H$. stipulacea more than $2000 \mathrm{~m}^{2}$ are observed in Mediterranean Sea (Sghaier 479 et al., 2011).

\section{Conclusion}

Depth was not an environmental factor influencing the total abundance of benthic dinoflagellates however it partially structured the distribution of some dinoflagellates genera suggesting interaction with other parameters. Thereby, monitoring of abundance of benthic dinoflagellates conducted at shallow depths may underestimate the risk due to presence of different benthic dinoflagellates genera. However, this common method seems to be appropriate for the Caribbean area where the main sanitary trouble is due to Gambierdiercus spp.. presence which is found in higher abundance at shallow depth. A temporal survey must be conducted at shallow depths in order to know population dynamic

490 of Gambierdiscus spp. in Guadeloupe Island.

491

\section{$\underline{\text { Acknowledgements }}$}

493 This study was made possible by the "Collectivité Territoriale de la Martinique". This 494 study was partly funded by the PROLITENSAN project ("Fondation de France") and our 495 group is part of the National French GDR PHYCOTOX (CNRS and Ifremer). 


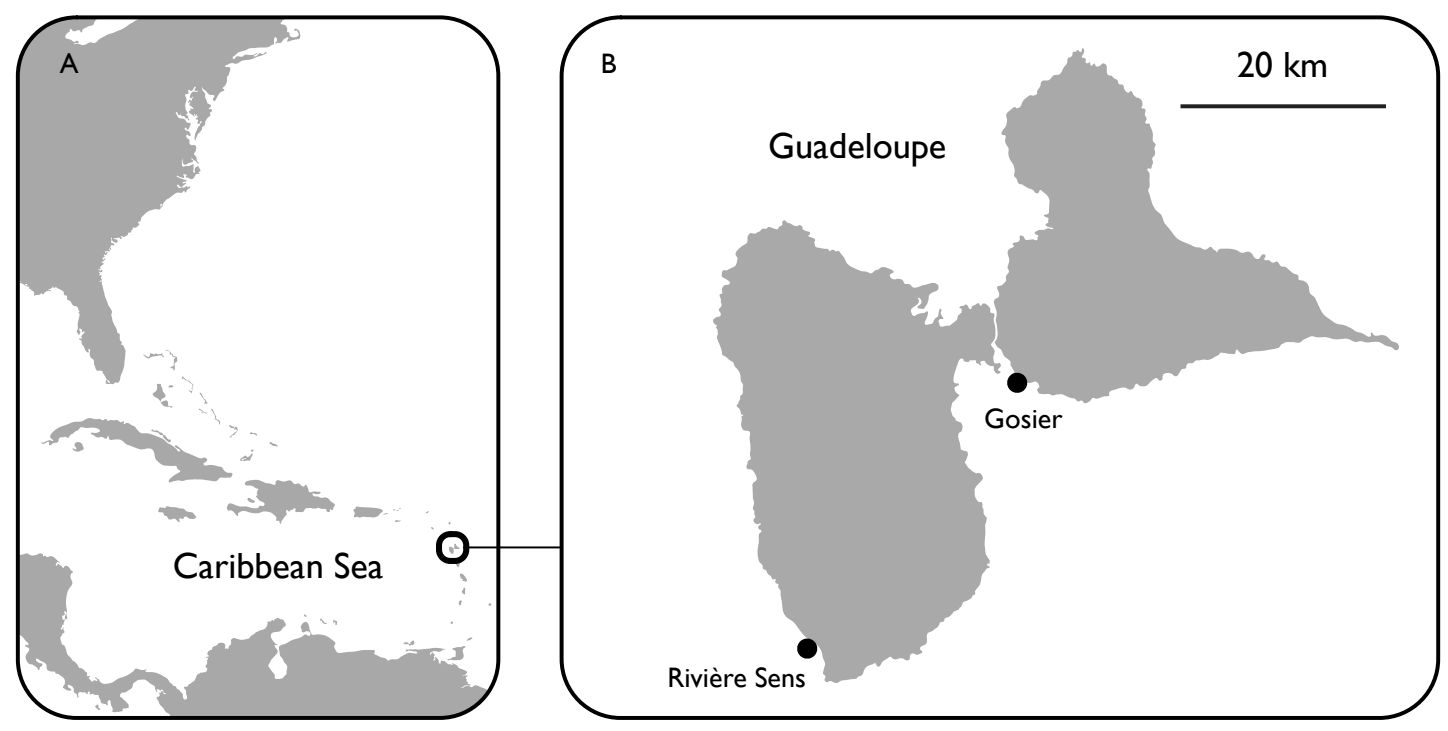

498 Figure 1: A: Location of Guadeloupe archipelago in the Caribbean Sea, B: Location of

499 Rivière Sens (deep site) and Gosier (shallow site) in Guadeloupe. 

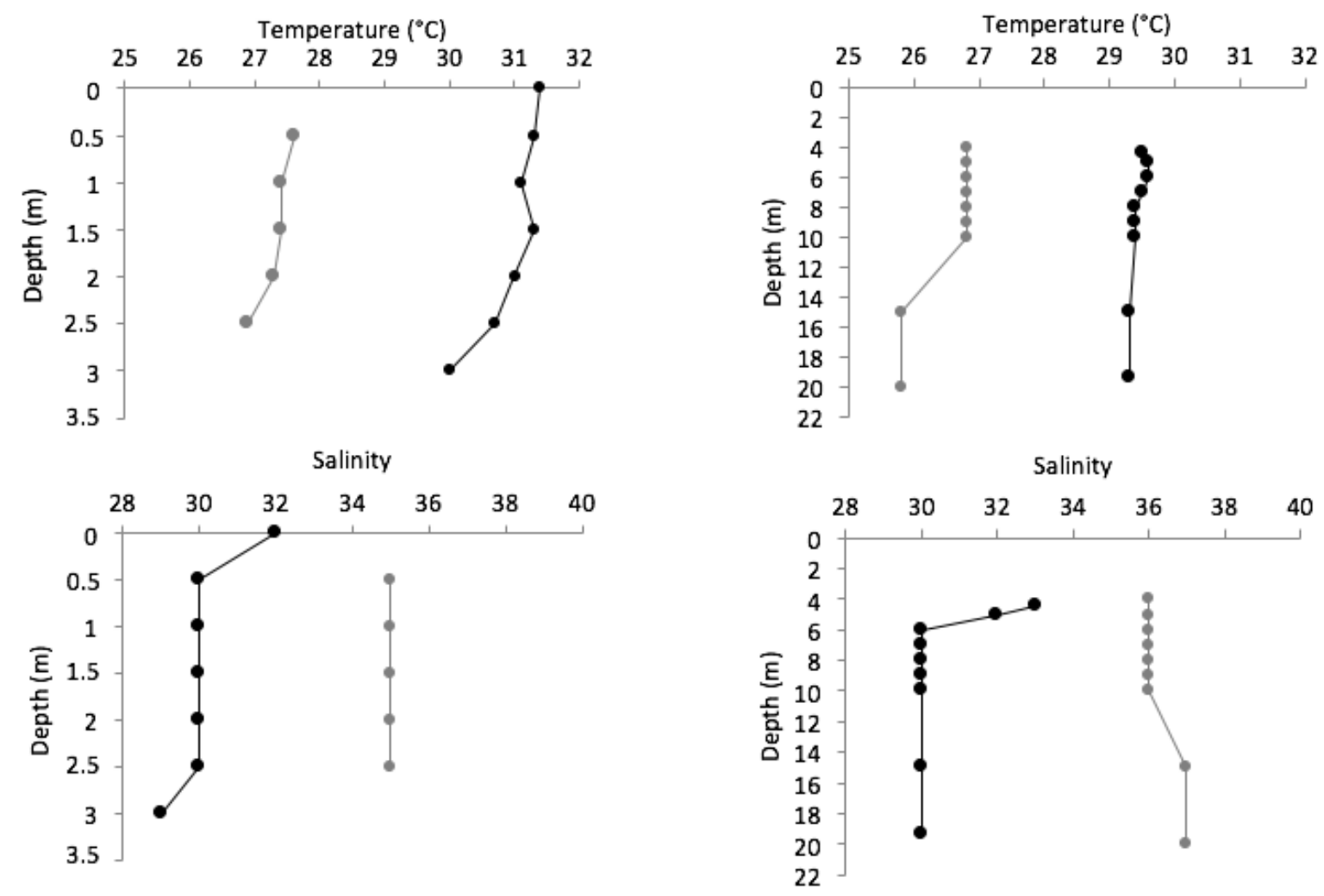

513

wet season

dry season

514 Figure 2. Profiles of temperature and salinity during the wet (black) and the dry (grey)

515 seasons at Gosier (graphs on the left) and Rivière Sens (graphs on the right).

516 

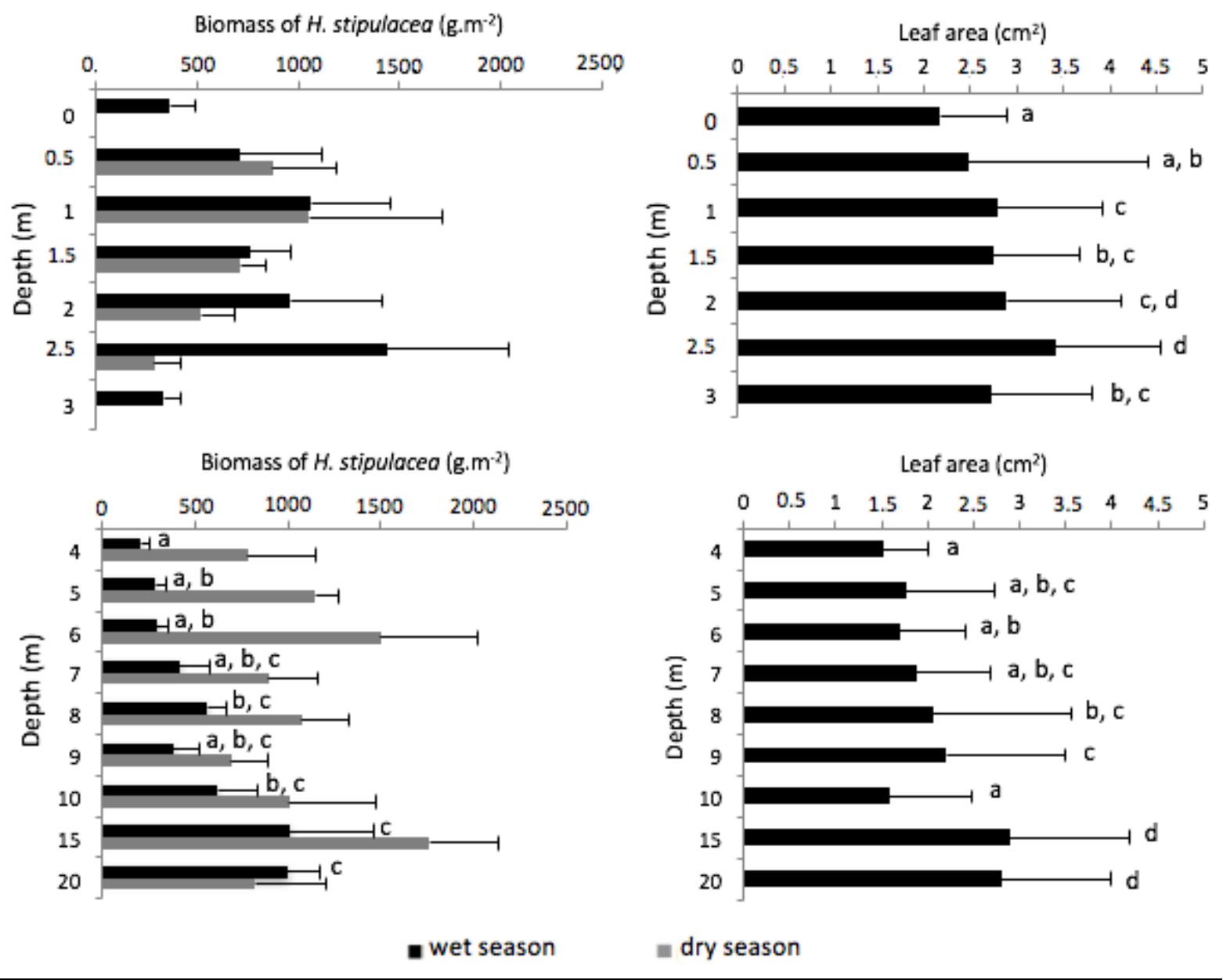

519 Figure 3: Left. Mean Halophila stipulacea biomass (left) and leaf surface ( $\mathrm{cm}^{2}$ per leaf)

520 (right) ( $\pm \mathrm{SD}, n=3)$ at different depths at Gosier (above) and Rivière Sens (below) during

521 the wet (black) and the dry seasons (grey). Significant differences between depths are

522 indicated with letters (Kruskal Wallis test and Dunn test, $\alpha=0,05$ ).

523 It should be noticed that, in each station, the trend of H. stipulacea exhibits different trends

524 in distribution with depth in the wet than in the dry season. 

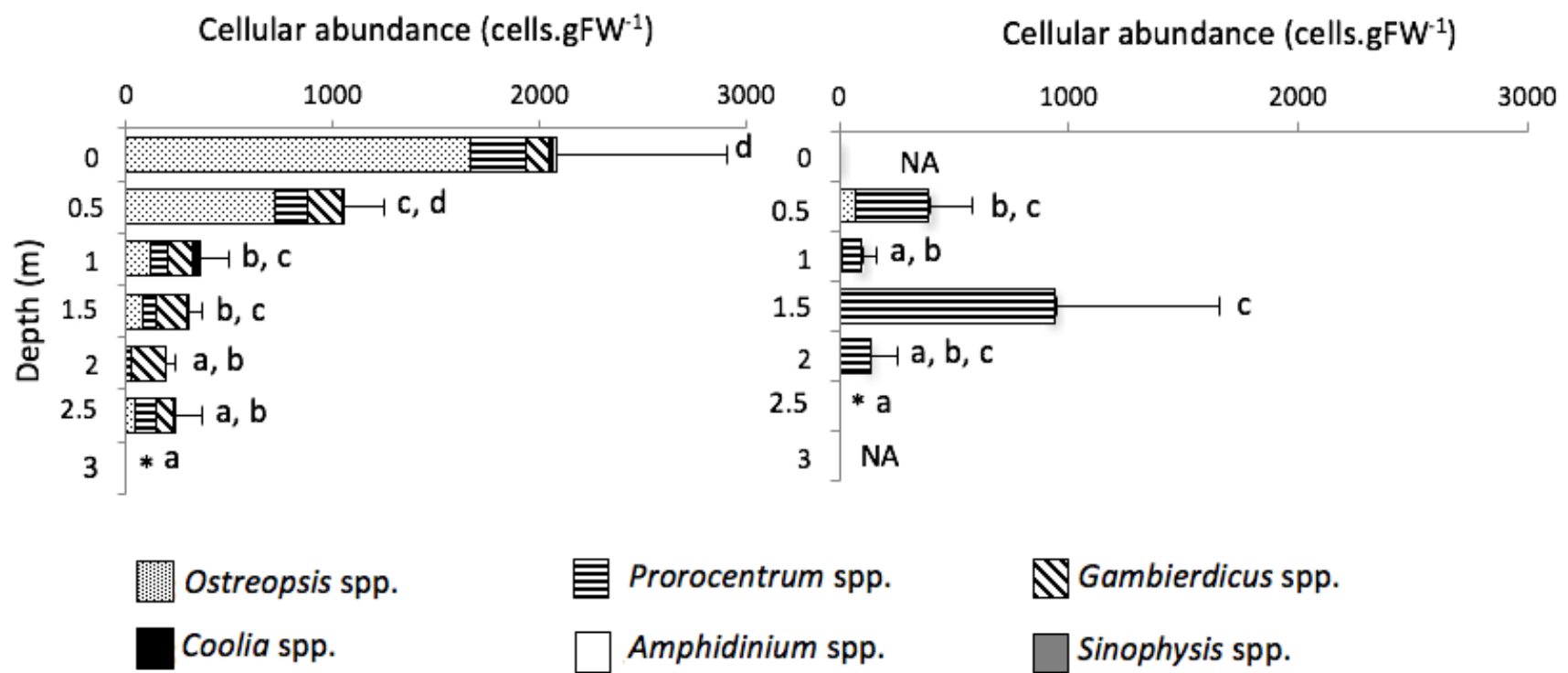

528

529 Figure 4: Abundance of benthic toxic dinoflagellates with depth during the wet (left) and

530 the dry (right) season at Gosier. "*” indicates no cell found but depth sampled and "NA"

531 data no available because no macrophyte was found. Significant differences between

532 depths are indicated with letters (Kruskal-Wallis test and Dunn test, $\alpha=0,05$ ).

533

534

535

536

537 


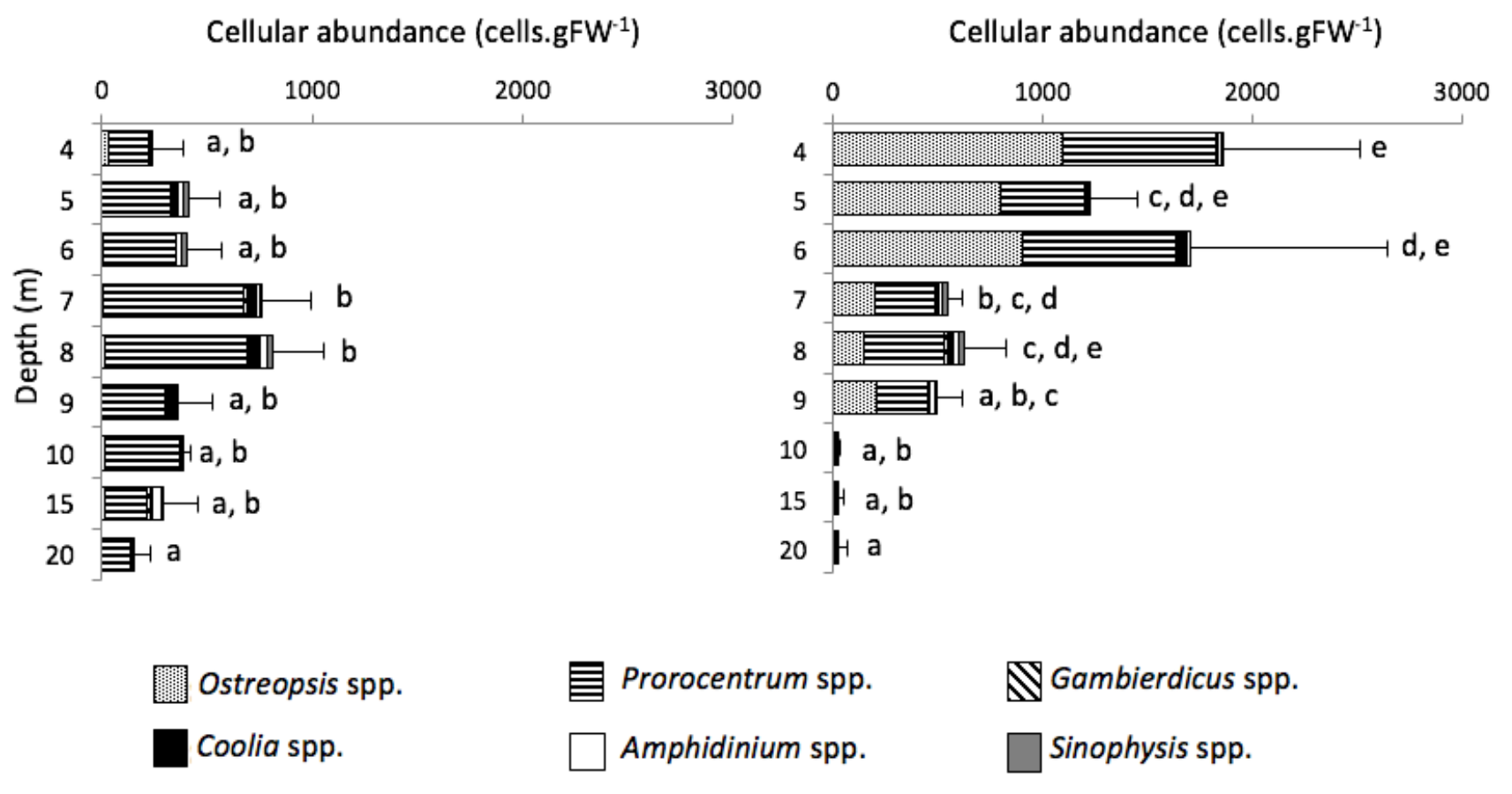

540 Figure 5: Abundances of benthic toxic dinoflagellates according to depth during the wet

541 (left) and the dry (right) season at Rivière Sens. Significant differences between depths are

542 indicated with letters (Kruskal Wallis test and Dunn test, $\alpha=0,05$ ). 


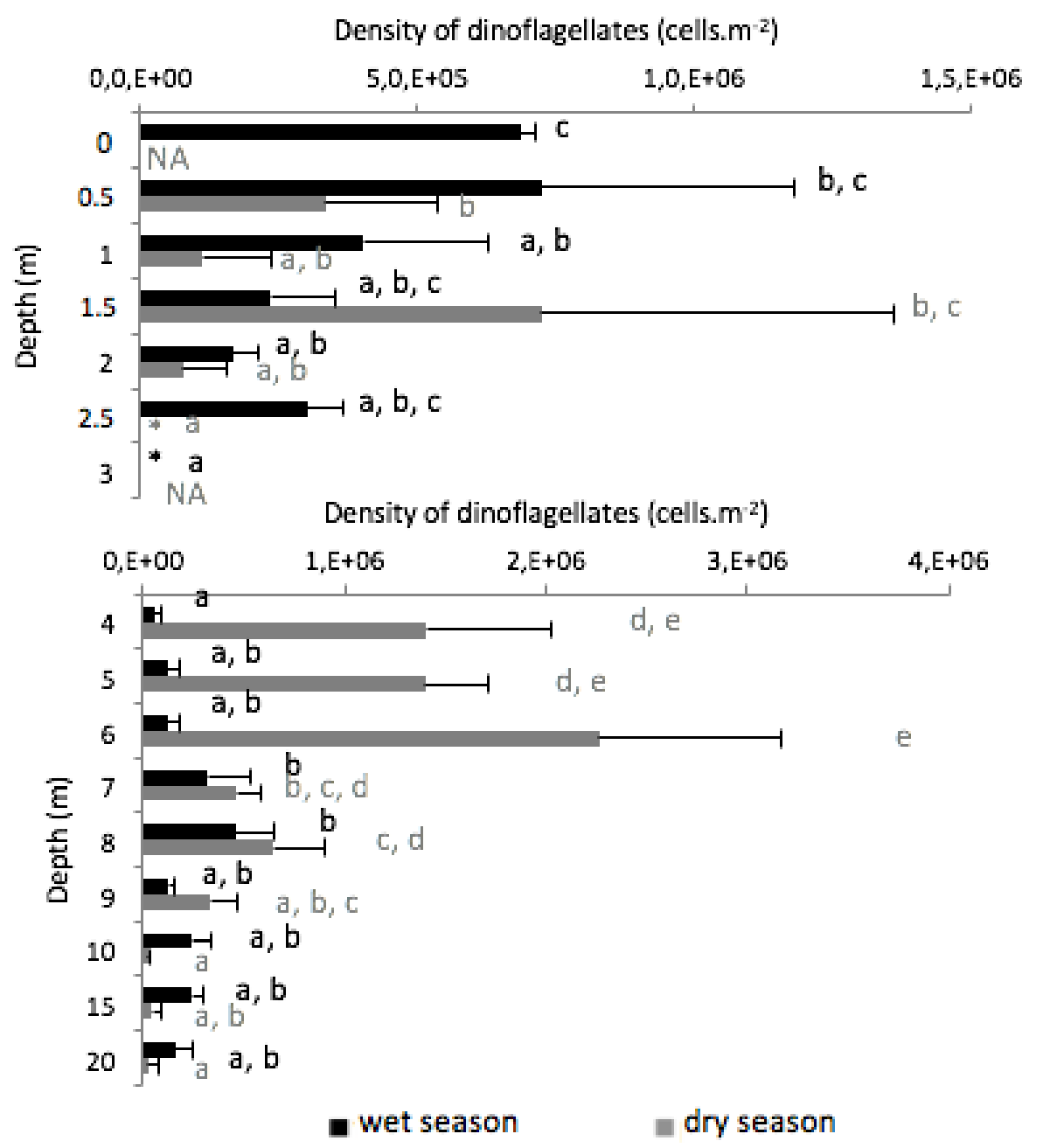

544

545 Figure 6: Mean density of benthic dinoflagellates \pm SD according to depth at Gosier

546 (above) and at Rivière Sens (below) for the wet (black) and the dry season (grey). "*”

547 indicates no cell found but depth sampled and "NA" data no available because no

548 macrophyte was found. Significant differences between depths are indicated with letters

549 (Kruskal Wallis test and Dunn test, $\alpha=0,05$ ).

550

551 
552 Table 1: Relations between depth $(\mathrm{m})$, temperature $\left({ }^{\circ} \mathrm{C}\right)$, salinity, $H$. stipulacea biomass

$553\left(\mathrm{~g} \cdot \mathrm{m}^{-2}\right)$, total abundances and abundances of Ostreopsis, Prorocentrum, Gambierdiscus,

554 Coolia, Amphidinium and Sinophysis genera (cells.gFW ${ }^{-1}$ ). Coefficient $\mathrm{r}_{s}$ of Spearman,

555 bold when significant with $\mathrm{p}<0.05$, bold and underlined when significant with $\mathrm{p}<0.01$.

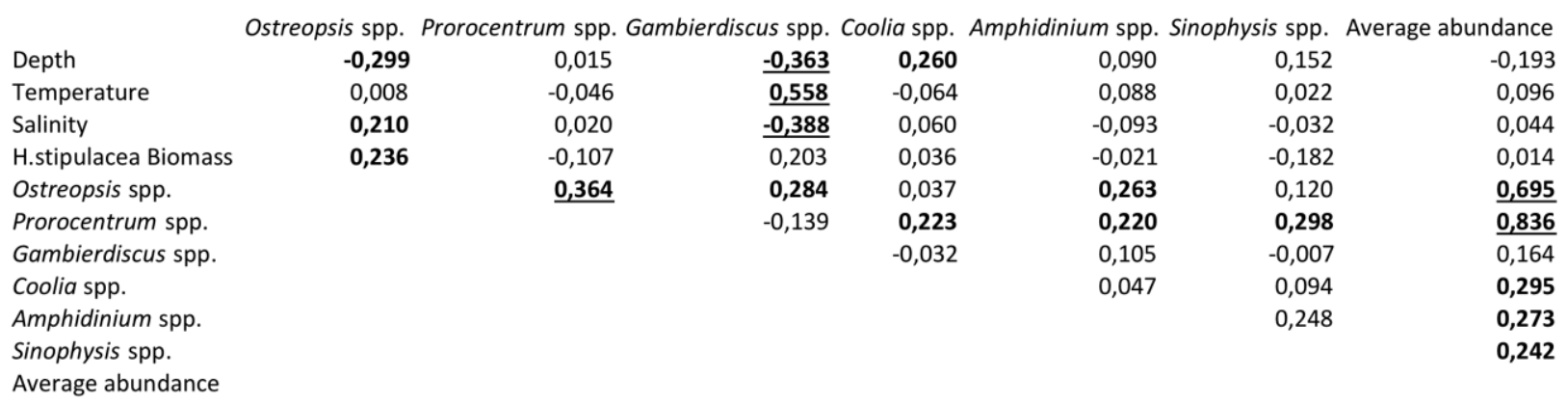




\section{$\underline{\text { References }}$}

Abbate, M., Bordone, A., Cerrati, G., Festa, T.D., Melchiorre, N., Pastorelli, A.M., Peirano, A., Rosaria Petruzzelli, M., Ungaro, N., 2012. A new method for sampling potentially toxic benthic dinoflagellates. Cryptogam. Algol. 33, 165-170.

Accoroni, S., Percopo, I., Cerino, F., Romagnoli, T., Pichierri, S., Perrone, C., Totti, C., 2015. Allelopathic interactions between the HAB dinoflagellate Ostreopsis cf. ovata and macroalgae. Harmful Algae 49, 147-155.

Adachi, M., Fukuyo, Y., 1979. The thecal structure of marine toxic dinoflagellate Gambierdiscus toxicus gen. et sp. nov. collected in a ciguatera-endemic area. J. Jpn. Soc. Sci. Fish. 45, 67-71.

Ahmed, F.E., 1991. Naturally occurring fish and shellfish poisons. Seafood safety, Washington, D.C.

Ajani, P., Harwood, D.T., Murray, S.A., 2017. Recent trends in marine phycotoxins from australian coastal waters. Mar. Drugs 15, 1-20.

Alcala, A.C., Alcala, L.C., Garth, J.S., Yasumura, D., Yasumoto, T., 1988. Human fatality due to ingestion of the crab Demania reynaudii that contained a palytoxin-like toxin. Toxicon 26, 105-107.

Aligizaki, K., Katikou, P., Milandri, A., Diogène, J., 2011. Occurrence of palytoxin-group toxins in seafood and future strategies to complement the present state of the art. Toxicon, Palytoxin-group toxins 57, 390-399.

Aligizaki, K., Nikolaidis, G., 2006. The presence of the potentially toxic genera Ostreopsis and Coolia (Dinophyceae) in the North Aegean Sea, Greece. Harmful Algae 5, 717-730.

Bagnis, R., 1981. L'ichtyosarcotoxisme de type ciguatera: phénomène complexe de biologie marine et humaine. Oceanol. Acta 4, 375-387.

Ballantine, D.L., Bardales, A.T., Tosteson, T.R., 1985. Seasonal abundance of Gambierdiscus toxicus and Ostreopsis sp. in coastal waters of southwest Puertorico. Proceeding of the Fifth International Coral Reef Congress, Tahiti, pp. 417422.

Ballantine, D.L., Tosteson, T.R., Bardales, A.T., 1988. Population dynamics and toxicity of natural populations of benthic dinoflagellates in southwestern Puerto Rico. J. Exp. Mar. Biol. Ecol. 119, 201-212.

Bauder, A.G., Cembella, A.D., Bricelj, V.M., Quilliam, M.A., 2001. Uptake and fate of diarrhetic shellfish poisoning toxins from the dinoflagellate Argopecten irradians, Prorocentrum lima in the bay scallop Argopecten irradians. Mar. Ecol. Prog. Ser. 213, 39-52.

Becking, L.E., Bussel, T.C.J.M. van, Debrot, A.O., Christianen, M.J.A., 2014. First record of a caribbean green turtle (Chelonia mydas) grazing on invasive seagrass (Halophila stipulacea). Caribb. J. Sci. 48, 162-163.

Ben-Gharbia, H., Yahia, O.K.-D., Amzil, Z., Chomérat, N., Abadie, E., Masseret, E., Sibat, M., Zmerli Triki, H., Nouri, H., Laabir, M., 2016. Toxicity and growth assessments of three thermophilic benthic dinoflagellates (Ostreopsis cf. ovata, Prorocentrum lima and Coolia monotis) developing in the Southern Mediterranean Basin. Toxins $8,1-38$.

Berdalet, E., Fleming, L.E., Gowen, R., Davidson, K., Hess, P., Backer, L.C., Moore, S.K., Hoagland, P., Enevoldsen, H., 2015. Marine harmful algal blooms, human health 
and wellbeing: challenges and opportunities in the 21st century. J. Mar. Biol. Assoc. U. K. 1-31.

Berdalet, E., Tester, P.A., Chinain, M., Fraga, S., Lemée, R., Litaker, W., Penna, A., Usup, G., Vila, M., Zingone, A., 2017. Harmful algal blooms in benthic systems: Recent progress and future research. Oceanography 30, 36-45.

Bomber, J.W., Rubio, M.G., Norris, D.R., 1989. Epiphytism of dinoflagellates associated with the disease ciguatera: substrate specificity and nutrition. Phycologia 28, 360368.

Botana, L.M., 2014. Seafood and Freshwater Toxins: Pharmacology, Physiology, and Detection, Third Edition. CRC Press.

Burkholder, J.M., Glibert, P.M., Skelton, H.M., 2008. Mixotrophy, a major mode of nutrition for harmful algal species in eutrophic waters. Harmful Algae, HABs and Eutrophication 8, 77-93. doi:10.1016/j.hal.2008.08.010

Chang, F.H., Shimizu, Y., Hay, B., Stewart, R., Mackay, G., Tasker, R., 2000. Three recently recorded Ostreopsis spp. (Dinophyceae) in New Zealand: Temporal and regional distribution in the upper North Island from 1995 to 1997. N. Z. J. Mar. Freshw. Res. 34, 29-39.

Chinain, M., Darius, H.T., Ung, A., Cruchet, P., Wang, Z., Ponton, D., Laurent, D., Pauillac, S., 2010. Growth and toxin production in the ciguatera-causing dinoflagellate Gambierdiscus polynesiensis (Dinophyceae) in culture. Toxicon Off. J. Int. Soc. Toxinology 56, 739-750.

Chinain, M., Gatti, C., Roué, M., Laurent, D., Darius, H.T., 2014. Ciguatéra: aspects écologiques, biologiques et toxicologiques. Rev. Francoph. Lab., Micro-organismes pathogènes de l'eau (2) 2014, 27-39.

Chomérat, N., 2016. Studies on the benthic genus Sinophysis (Dinophysales, Dinophyceae): I. a taxonomic investigation from Martinique Island, including two new species and elucidation of the epithecal plate pattern. Phycologia 55, 445-461. doi:10.2216/16-24.1

Ciminiello, P., Dell'Aversano, C., Iacovo, E.D., Fattorusso, E., Forino, M., Tartaglione, L., Benedettini, G., Onorari, M., Serena, F., Battocchi, C., Casabianca, S., Penna, A., 2014. First finding of Ostreopsis cf. ovata toxins in marine aerosols. Environ. Sci. Technol. 48, 3532-3540.

Cloern, J.E., Schraga, T.S., Lopez, C.B., Knowles, N., Grover Labiosa, R., Dugdale, R., 2005. Climate anomalies generate an exceptional dinoflagellate bloom in San Francisco Bay. Geophys. Res. Lett. 32, L14608.

Cohu, S., Lemée, R., 2012. Vertical distribution of the toxic epibenthic dinoflagellates Ostreopsis cf. ovata, Prorocentrum lima and Coolia monotis in the NW Mediterranean Sea. CBM-Cah. Biol. Mar. 53, 373-380.

Cohu, S., Mangialajo, L., Thibaut, T., Blanfuné, A., Marro, S., Lemée, R., 2013. Proliferation of the toxic dinoflagellate Ostreopsis cf. ovata in relation to depth, biotic substrate and environmental factors in the North West Mediterranean Sea. Harmful Algae 24, 32-44.

Delgado, G., Lechuga, C.H., Troccoli, L., Santos, K., 2006. Spatial-temporal variation of four species of toxic epiphytic dinoflagellates of Prorocentrum genus in NW of Cuba. Rev. Cuba. Investig. Pesq. 24, 5-9.

Delgado, G., Lechuga-Devéze, C.H., Popowski, G., Troccoli, L., Salinas, C.A., 2005. Epiphytic dinoflagellates associated with ciguatera in the northwestern coast of Cuba. Rev. Biol. Trop. 54, 299-310.

Delia, A.S., Caruso, G., Melcarne, L., Caruso, G., Parisi, S., Laganà, P., 2015. Biological toxins from marine and freshwater microalgae, in: Microbial Toxins and Related 
Contamination in the Food Industry, SpringerBriefs in Molecular Science. Springer International Publishing, pp. 13-55.

den Hartog, C., 1970. The sea-grasses of the world. Amsterdam, London: North-Holland Publishing Company. Int. Rev. Gesamten Hydrobiol. Hydrogr. 56, 141-141.

Dickey, R.W., Plakas, S.M., 2010. Ciguatera: a public health perspective. Toxicon 56, 123-136.

Faust, M.A., 2009. Ciguatera-causing dinoflagellates in a coral-reef mangrove ecosystem, Belize. Atoll Res. Bull. 569, 1-30.

Faust, M.A., 1997. Three new benthic species of Prorocentrum (Dinophyceae) from Belize: $P$. norrisianum sp. nov., $P$. tropicalis sp. nov., and $P$. reticulaum sp. nov.1. J. Phycol. 33, 851-858.

Faust, M.A., Gulledge, R.A., 2002. Identifying harmful marine dinoflagellates. Contrib. U. S. Natl. Herb. 42, 1-144.

Fraga, S., Penna, A., Bianconi, I., Paz, B., Zapata, M., 2008. Coolia canariensis sp. nov. (Dinophyceae) a new nontoxic epithytic benthic dinoflagellate from the Canary Islands. J. Phycol. 44, 1060-1070.

Fraga, S., Rodríguez, F., 2014. Genus Gambierdiscus in the Canary Islands (NE Atlantic Ocean) with description of Gambierdiscus silvae sp. nov., a new potentially toxic epiphytic benthic dinoflagellate. Protist 165, 839-853.

Friedman, M.A., Fleming, L.E., Fernandez, M., Bienfang, P., Schrank, K., Dickey, R., Bottein, M.-Y., Backer, L., Ayyar, R., Weisman, R., Watkins, S., Granade, R., Reich, A., 2008. Ciguatera Fish Poisoning: Treatment, Prevention and Management. Mar. Drugs 6, 456-479.

García-Portela, M., Riobó, P., Franco, J.M., Bañuelos, R.M., Rodríguez, F., 2016. Genetic and toxinological characterization of North Atlantic strains of the dinoflagellate Ostreopsis and allelopathic interactions with toxic and non-toxic species from the genera Prorocentrum, Coolia and Gambierdiscus. Harmful Algae 60, 57-69.

Gleibs, S., Mebs, D., 1999. Distribution and sequestration of palytoxin in coral reef animals. Toxicon 37, 1521-1527.

Glibert, P., Anderson, D., Gentien, P., Granéli, E., Sellner, K., 2005. The global, complex phenomena of harmful algal blooms. Oceanography 18, 136-147.

Graneli, E., Weberg, M., Salomon, P.S., 2008. Harmful algal blooms of allelopathic microalgal species: The role of eutrophication. Harmful Algae 8, 94-102.

Grzebyk, D., Berland, B., Thomassin, B.A., Bosi, C., Arnoux, A., 1994. Ecology of ciguateric dinoflagellates in the coral reef complex of Mayotte Island (S.W. Indian Ocean). J. Exp. Mar. Biol. Ecol. 178, 51-66.

Hallegraeff, G.M., 2010. Ocean climate change, phytoplankton community responses, and harmful algal blooms: a formidable predictive challenge 1. J. Phycol. 46, 220-235.

Hallegraeff, G.M., 1993. A review of harmful algal blooms and their apparent global increase. Phycologia 32, 79-99.

Heredia-Tapia, A., Arredondo-Vega, B.O., Nuñez-Vázquez, E.J., Yasumoto, T., Yasuda, M., Ochoa, J.L., 2002. Isolation of Prorocentrum lima (Syn. Exuviaella lima) and diarrhetic shellfish poisoning (DSP) risk assessment in the Gulf of California, Mexico. Toxicon 40, 1121-1127.

Holmes, M.J., Lewis, R.J., Jones, A., Hoy, A.W.W., 1995. Cooliatoxin, the first toxin from Coolia monotis (dinophyceae). Nat. Toxins 3, 355-362.

Holmes, M.J., Teo, S.L.M., 2002. Toxic marine dinoflagellates in Singapore waters that cause seafood poisonings. Clin. Exp. Pharmacol. Physiol. 29, 829-836. 
Jauzein, C., Couet, D., Blasco, T., Lemée, R., 2017. Uptake of dissolved inorganic and organic nitrogen by the benthic toxic dinoflagellate Ostreopsis cf. ovata. Harmful Algae 65, 9-18.

Jauzein, C., Fricke, A., Mangialajo, L., Lemée, R., 2016. Sampling of Ostreopsis cf. ovata using artificial substrates: Optimization of methods for the monitoring of benthic harmful algal blooms. Mar. Pollut. Bull. 107, 300-304.

Kumagai, M., Yanagi, T., Murata, M., Yasumoto, T., Kat, M., Lassus, P., RodriguezVazquez, J.A., 1986. Okadaic acid as the causative toxin of diarrhetic shellfish poisoning in Europe. Agric. Biol. Chem. 50, 2853-2857.

Landsberg, J.H., Van Dolah, F.M., Doucette, G.J., 2005. Marine and Estuarine Harmful Algal Blooms: Impacts on Human and Animal Health, in: Oceans and Health: Pathogens in the Marine Environment. Belkin and Colwell, pp. 165-215.

Legrand, C., Rengefors, K., Fistarol, G.O., Granéli, E., 2003. Allelopathy in phytoplankton - biochemical, ecological and evolutionary aspects. Phycologia 42, 406-419.

Lehane, L., Lewis, R.J., 2000. Ciguatera: recent advances but the risk remains. Int. J. Food Microbiol. 61, 91-125.

Lenoir, S., Ten-Hage, L., Turquet, J., Quod, J.-P., Bernard, C., Hennion, M.-C., 2004. First evidence of palytoxin analogues from an Ostreopsis mascarenensis (Dinophyceae) benthic bloom in southwestern Indian Ocean. J. Phycol. 40, 1042-1051.

Lewis, R.J., Holmes, M.J., 1993. Origin and transfer of toxins involved in ciguatera. Comp. Biochem. Physiol. C Pharmacol. Toxicol. Endocrinol. 106, 615-628.

Loeffler, C., Richlen, M., Brandt, M., Smith, T., 2015. Effects of grazing, nutrients, and depth on the ciguatera-causing dinoflagellate Gambierdiscus in the US Virgin Islands. Mar. Ecol. Prog. Ser. 531, 91-104.

Luo, Z., Zhang, H., Krock, B., Lu, S., Yang, W., Gu, H., 2017. Morphology, molecular phylogeny and okadaic acid production of epibenthic Prorocentrum (Dinophyceae) species from the northern South China Sea. Algal Res. 22, 14-30.

Mangialajo, L., Bertolotto, R., Cattaneo-Vietti, R., Chiantore, M., Grillo, C., Lemee, R., Melchiorre, N., Moretto, P., Povero, P., Ruggieri, N., 2008. The toxic benthic dinoflagellate Ostreopsis ovata: Quantification of proliferation along the coastline of Genoa, Italy. Mar. Pollut. Bull. 56, 1209-1214.

Mangialajo, L., Fricke, A., Perez-Gutierrez, G., Catania, D., Jauzein, C., Lemee, R., 2017. Benthic Dinoflagellate Integrator (BEDI): A new method for the quantification of benthic harmful algal blooms. Harmful Algae 64, 1-10.

Mangialajo, L., Ganzin, N., Accoroni, S., Asnaghi, V., Blanfuné, A., Cabrini, M., Cattaneo-Vietti, R., Chavanon, F., Chiantore, M., Cohu, S., Costa, E., Fornasaro, D., Grossel, H., Marco-Miralles, F., Masó, M., Reñé, A., Rossi, A.M., Sala, M.M., Thibaut, T., Totti, C., Vila, M., Lemée, R., 2011. Trends in Ostreopsis proliferation along the Northern Mediterranean coasts. Toxicon, Palytoxin-group toxins 57, 408-420.

Mariani, S., Alcoverro, T., 1999. A multiple-choice feeding-preference experiment utilising seagrasses with a natural population of herbivorous fishes. Mar. Ecol. Prog. Ser. 189, 295-299.

Martinez-Cruz, Okolodkov, Y.B., aguilar-Trujillo, C., Herrera-silveira, J.A., 2015. Epiphytic dinoflagellates on the seagrass Thalassia testudinum at Dzilam, southeastern Gulf of Mexico. Cymbella 2-9.

Monti, M., Minocci, M., Beran, A., Iveša, L., 2007. First record of Ostreopsis cf. ovata on macroalgae in the Northern Adriatic Sea. Mar. Pollut. Bull. 54, 598-601.

Morton, S.L., Faust, M.A., 1997. Survey of toxic epiphytic dinoflagellates from the belizean barrier reef ecosystem. Bull. Mar. Sci. 61, 899-906. 
Morton, S.L., Norris, D.R., Bomber, J.W., 1992. Effect of temperature, salinity and light intensity on the growth and seasonality of toxic dinoflagellates associated with ciguatera. J. Exp. Mar. Biol. Ecol. 157, 79-90.

Nascimento, S.M., Salgueiro, F., Menezes, M., Oliveira, F. de A., Magalhães, V.C.P., De Paula, J.C., Morris, S., 2016. Prorocentrum lima from the South Atlantic: Morphological, molecular and toxicological characterization. Harmful Algae 57, Part A, 39-48.

Okolodkov, Y.B., Campos Bautista, G., Gárate-Lizárraga, I., González-González, J.A.G., Hoppenrath, M., Arenas, V., 2007. Seasonal changes of benthic and epiphytic dinoflagellates in the Veracruz reef zone, Gulf of Mexico. Aquat. Microb. Ecol. 47, 223-237.

Okolodkov, Y.B., Del Carmen Merino-Virgilio, F., Aké-Castillo, J.A., Aguilar-Trujillo, A.C., Espinosa-Matías, S., Herrera-silveira, A., 2014. Seasonal changes in epiphytic dinoflagellate assemblages near the northern coast of the Yucatan Peninsula, Gulf of Mexico. Acta Bot. Mex. 107, 121-151.

Onuma, Y., Satake, M., Ukena, T., Roux, J., Chanteau, S., Rasolofonirina, N., Ratsimaloto, M., Naoki, H., Yasumoto, T., 1999. Identification of putative palytoxin as the cause of clupeotoxism. Toxicon 37, 55-65.

Parsons, M.L., Brandt, A.L., Ellsworth, A., Leynse, A.K., Rains, L.K., Anderson, D.M., 2017. Assessing the use of artificial substrates to monitor Gambierdiscus populations in the Florida Keys. Harmful Algae 68, 52-66. doi:10.1016/j.hal.2017.07.007

Parsons, M.L., Preskitt, L.B., 2007. A survey of epiphytic dinoflagellates from the coastal waters of the island of Hawai'i. Harmful Algae 6, 658-669.

Penna, A., Vila, M., Fraga, S., Giacobbe, M.G., Andreoni, F., Riobó, P., Vernesi, C., 2005. Characterization of Ostreopsis and Coolia (Dinophyceae) isolates in the western Mediterranean Sea based on morphology, toxicity and internal trancribed spacer 5.8s rDNA seaquence. J. Phycol. 41, 212-225.

Pezzolesi, L., Guerrini, F., Ciminiello, P., Dell'Aversano, C., Dello Iacovo, E., Fattorusso, E., Forino, M., Tartaglione, L., Pistocchi, R., 2012. Influence of temperature and salinity on Ostreopsis cf. ovata growth and evaluation of toxin content through HR LC-MS and biological assays. Water Res. 46, 82-92.

Pezzolesi, L., Pistocchi, R., Fratangeli, F., Dell'Aversano, C., Dello Iacovo, E., Tartaglione, L., 2014. Growth dynamics in relation to the production of the main cellular components in the toxic dinoflagellate Ostreopsis cf. ovata. Harmful Algae 36, 1-10.

Pistocchi, R., Pezzolesi, L., Guerrini, F., Vanucci, S., Dell'Aversano, C., Fattorusso, E., 2011. A review on the effects of environmental conditions on growth and toxin production of Ostreopsis ovata. Toxicon 57, 421-428.

Procaccini, G., Acunto, S., Famà, P., Maltagliati, F., 1999. Structural, morphological and genetic variability in Halophila stipulacea (Hydrocharitaceae) populations in the western Mediterranean. Mar. Biol. 135, 181-189.

Rahman Sha, M.M., An, S.-J., Lee, J.-B., 2014. Occurrence of sand-dwelling and epiphytic dinoflagellates including potentially toxic species along the coast of Jeju Island, Korea. J. Fish. Aquat. Sci. 9, 141-156.

Randall, J.E., 2005. Review of clupeotoxism, an often fatal illness from the consumption of clupeoid fishes. Pac. Sci. 59, 73-77.

Rhodes, L., Adamson, J., Suzuki, T., Briggs, L., Garthwaite, I., 2000. Toxic marine epiphytic dinoflagellates, Ostreopsis siamensis and Coolia monotis (Dinophyceae), in New Zealand. N. Z. J. Mar. Freshw. Res. 34, 371-383. 
Richlen, M.L., Lobel, P.S., 2011. Effects of depth, habitat, and water motion on the abundance and distribution of ciguatera dinoflagellates at Johnston Atoll, Pacific Ocean. Mar. Ecol. Prog. Ser. 421, 51-66.

Ruiz, H., Ballantine, D.L., 2004. Occurrence of the seagrass Halophila stipulacea in the tropical West Atlantic. Bull. Mar. Sci. 75, 131-135.

Sghaier, Y.R., Zakhama-Sraieb, R., Benamer, I., Charfi-Cheikhrouha, F., 2011. Occurrence of the seagrass Halophila stipulacea (Hydrocharitaceae) in the southern Mediterranean Sea. Bot. Mar. 54, 575-582.

Shears, N.T., Ross, P.M., 2009. Blooms of benthic dinoflagellates of the genus Ostreopsis; an increasing and ecologically important phenomenon on temperate reefs in New Zealand and worldwide. Harmful Algae 8, 916-925.

Shumway, S.E., 1990. A review of the effects of algal blooms on shellfish and aquaculture. J. World Aquac. Soc. 21, 65-104.

Sugg, L.M., VanDolah, F.M., 1999. No evidence for an allelopathic role of okadaic acid among ciguatera-associated dinoflagellates. J. Phycol. 35, 93-103.

Taylor, F.J.R., 1985. The distribution of the dinoflagellates G. toxicus in the Eastern Caribbean, in: Proceedings Of The Fifth International Coral Reef Congress. Tahiti, pp. 423-428.

Ten-Hage, L., Turquet, J., Quod, J.-P., Puiseux-Dao, S., Coute, A., 2000. Prorocentrum borbonicum sp. nov. (Dinophyceae), a new toxic benthic dinoflagellate from the southwestern Indian Ocean. Phycologia 39, 296-301.

Tester, P.A., 1994. Harmful marine phytoplankton and shellfish toxicity potential consequences of climate change. Ann. N. Y. Acad. Sci. 740, 69-76.

Tester, P.A., Feldman, R.L., Nau, A.W., Faust, M.A., Litaker, R.W., 2009. Ciguatera fish poisoning in the Caribbean. Smithson. Contrib. Mar. Sci. 0, 301-311.

Tester, P.A., Kibler, S.R., Holland, W.C., Usup, G., Vandersea, M.W., Leaw, C.P., Teen, L.P., Larsen, J., Mohammad-Noor, N., Faust, M.A., Litaker, R.W., 2014. Sampling harmful benthic dinoflagellates: Comparison of artificial and natural substrate methods. Harmful Algae 39, 8-25.

Totti, C., Accoroni, S., Cerino, F., Cucchiari, E., Romagnoli, T., 2010. Ostreopsis ovata bloom along the Conero Riviera (northern Adriatic Sea): Relationships with environmental conditions and substrata. Harmful Algae 9, 233-239.

Valdiglesias, V., Prego-Faraldo, M.V., Pásaro, E., Méndez, J., Laffon, B., 2013. Okadaic acid: More than a diarrheic doxin. Mar. Drugs 11, 4328-4349.

Vanucci, S., Guerrini, F., Milandri, A., Pistocchi, R., 2010. Effects of different levels of Nand P-deficiency on cell yield, okadaic acid, DTX-1, protein and carbohydrate dynamics in the benthic dinoflagellate Prorocentrum lima. Harmful Algae 9, 590599.

Vila, M., Garcés, E., Masó, M., 2001. Potentially toxic epiphytic dinoflagellate assemblages on macroalgae in the NW Mediterranean. Aquat. Microb. Ecol. 26, $51-60$.

Willette, D.A., Ambrose, R.F., 2012. Effects of the invasive seagrass Halophila stipulacea on the native seagrass, Syringodium filiforme, and associated fish and epibiota communities in the Eastern Caribbean. Aquat. Bot. 103, 74-82.

Willette, D.A., Chalifour, J., Debrot, A.O.D., Engel, M.S., Miller, J., Oxenford, H.A., Short, F.T., Steiner, S.C.C., Védie, F., 2014. Continued expansion of the transAtlantic invasive marine angiosperm Halophila stipulacea in the Eastern Caribbean. Aquat. Bot. 112, 98-102.

Williams, S.L., 2007. Introduced species in seagrass ecosystems: Status and concerns. J. Exp. Mar. Biol. Ecol., The Biology and Ecology of Seagrasses 350, 89-110. 
Xu, Y., Richlen, M.L., Morton, S.L., Mak, Y.L., Chan, L.L., Tekiau, A., Anderson, D.M., 2014. Distribution, abundance and diversity of Gambierdiscus spp. from a ciguatera-endemic area in Marakei, Republic of Kiribati. Harmful Algae 34, 56-68.

Yasumoto, T., Nakajima, I., Bagnis, R., Adachi, R., 1977. Finding of a dinoflagellate as a likely culprit of ciguatera. Nippon Suisan Gakkaishi 43, 1021-1026.

Yasumoto, T., Seino, N., Murakami, Y., Murata, M., 1987. Toxins produced by benthic dinoflagellates. Biol. Bull. 172, 128-131.

Zingone, A., Siano, R., D’Alelio, D., Sarno, D., 2006. Potentially toxic and harmful microalgae from coastal waters of the Campania region (Tyrrhenian Sea, Mediterranean Sea). Harmful Algae 5, 321-337. 